\title{
Review \\ Mucosal Vaccines, Sterilizing Immunity, and the Future of SARS-CoV-2 Virulence
}

\author{
Daniele Focosi ${ }^{1, *(1)}$, Fabrizio Maggi ${ }^{2}\left(\mathbb{D}\right.$ ) and Arturo Casadevall ${ }^{3(1)}$ \\ 1 North-Western Tuscany Blood Bank, Pisa University Hospital, 56124 Pisa, Italy \\ 2 Department of Medicine and Surgery, University of Insubria, 21100 Varese, Italy; \\ fabrizio.maggi63@gmail.com \\ 3 Department of Medicine, Johns Hopkins School of Public Health and School of Medicine, \\ Baltimore, MD 21218, USA; acasade1@jhu.edu \\ * Correspondence: daniele.focosi@gmail.com; Tel.: +39-050-996541
}

check for updates

Citation: Focosi, D.; Maggi, F.; Casadevall, A. Mucosal Vaccines, Sterilizing Immunity, and the Future of SARS-CoV-2 Virulence. Viruses 2022, 14, 187. https://doi.org/ 10.3390/v14020187

Academic Editor: Ester Ballana Guix

Received: 24 December 2021

Accepted: 17 January 2022

Published: 19 January 2022

Publisher's Note: MDPI stays neutral with regard to jurisdictional claims in published maps and institutional affiliations.

Copyright: (C) 2022 by the authors. Licensee MDPI, Basel, Switzerland. This article is an open access article distributed under the terms and conditions of the Creative Commons Attribution (CC BY) license (https:// creativecommons.org/licenses/by/ $4.0 /)$.

\begin{abstract}
Sterilizing immunity after vaccination is desirable to prevent the spread of infection from vaccinees, which can be especially dangerous in hospital settings while managing frail patients. Sterilizing immunity requires neutralizing antibodies at the site of infection, which for respiratory viruses such as SARS-CoV-2 implies the occurrence of neutralizing IgA in mucosal secretions. Systemic vaccination by intramuscular delivery induces no or low-titer neutralizing $\operatorname{IgA}$ against vaccine antigens. Mucosal priming or boosting, is needed to provide sterilizing immunity. On the other side of the coin, sterilizing immunity, by zeroing interhuman transmission, could confine SARS-CoV-2 in animal reservoirs, preventing spontaneous attenuation of virulence in humans as presumably happened with the endemic coronaviruses. We review here the pros and cons of each vaccination strategy, the current mucosal SARS-CoV-2 vaccines under development, and their implications for public health.
\end{abstract}

Keywords: COVID-19; SARS-CoV-2; neutralizing antibody; BNT162b2; mRNA-1273; IgA; IgG; sterilizing immunity; mucosal vaccines; intranasal vaccine; oral vaccines

\section{Introduction}

Currently approved, intramuscularly injected COVID-19 vaccines (summarized in Figure 1) effectively reduce severity of disease and symptomatic cases, but still allow for asymptomatic infection. Most concerning from an epidemiological angle is that these vaccines allow transmission of SARS-CoV-2 and the ability of the virus to replicate in a vaccinated host has the potential for selecting vaccine-resistant variants. The current COVID-19 vaccines primarily induce antibodies of the IgG class (predominantly of $\operatorname{IgG}_{1}$ and $\operatorname{IgG}_{3}$ subclasses [1]), and little or no respiratory IgA. Although IgG levels are commonly monitored in serum to assess immunity, this isotype, unlike IgA, is not secreted into the mucosal lumen via the polymeric Ig receptor (pIgR), and must rely on passive transport to accumulate at these sites. After systemic administration of IgG, only one out of 1000 molecules in the serum reaches bronchoalveolar lavage (BAL) fluid [2-4]. Accordingly, IgG artificially fused to $\mathrm{PIgR}$-binding peptides are more represented in respiratory secretions and more protective in animal-challenge models [5].

Since serum IgG does not effectively penetrate to the mucosal space and serum measurements of vaccine-elicited $\mathrm{IgG}$ do not reflect protection from respiratory infection. Nevertheless, after priming with an intramuscular vaccine, subsequent inflammation triggers memory-B-cell migration and secretion of IgA at mucosal sites [6]. Furthermore, any inflammation in the airways enhances serum antibody penetration to the site such that serum immunity can provide early protection in the setting of a developing infection. Hence, intramuscular vaccination does provide some measure of protection in the nasal airways against SARS-CoV-2, as evident by reduction in symptomatic disease after infection. 


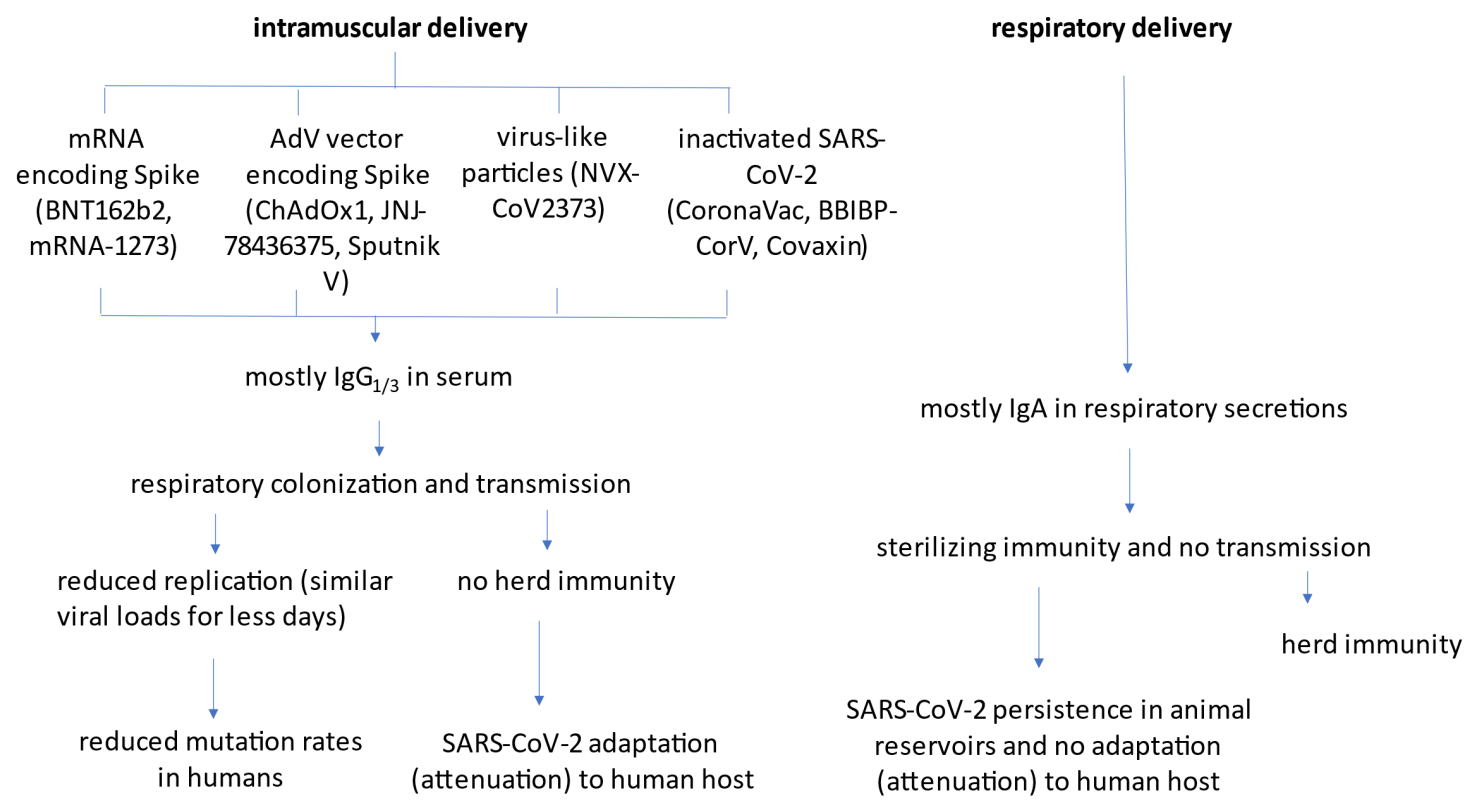

Figure 1. Schematic representation of mechanisms of action of currently approved intramuscular vaccines and next-generation mucosal vaccines.

Asymptomatic infection accounts for one third of SARS-CoV-2-positive nasopharyngeal swabs (NPS), and nearly $75 \%$ of cases asymptomatic at the time of the positive NPS will remain asymptomatic [7]. These estimates are likely to be even higher in vaccinees, where breakthrough infections have been demonstrated in asymptomatic subjects [8]. A person might feel fine, but actually harbor replicating SARS-CoV-2 in the nasopharyngeal mucosa and be able to transmit it to others. Given that systematic daily PCR testing would be too invasive and expensive within randomized controlled trials (RCT), several investigators have advocated use of random NPS PCR to improve estimates of vaccine efficacy (VE) against SARS-CoV-2 infection. Such viral-load measures could also be used to estimate efficacy against transmission, assuming the existence of a relationship between viral load and transmissibility [9]. Further supporting this view are data from clinically approved monoclonal antibodies $(\mathrm{mAb})$ to Spike protein-intravenous or subcutaneous injection of anti-SARS-CoV-2 mAbs leads to suboptimal bioavailability in airways, suppressing SARS-CoV-2 replication and lung injury, but allowing robust infection in nasal turbinates in animal models [10]. For this reason, topical delivery of anti-SARS-CoV-2 mAbs is being investigated [11].

We discuss here strategies to prevent asymptomatic carrier status in vaccinees (i.e., how to induce the so-called "sterilizing immunity"), and the theoretical risks of this approach.

\section{The Difference between Infection and Disease}

This simple question is difficult to answer precisely. Vaccines elicit immune responses that are in place when the host encounters the specific microbe. To examine how vaccines work it is important to distinguish between infection and disease. Infection is the acquisition of the microbe by the host while disease is a state of the host-microbe interaction when the host has incurred sufficient damage to affect homeostasis [12]. For most successful vaccines, the measure of efficacy has been reduction in disease since the frequency of infection was not measured. Most current vaccines elicit T-lymphocyte responses and primarily IgG, which provides protection against systemic infection. Robbins et al. proposed that vaccines functioned by neutralizing the infecting inoculum and that this process required a certain amount of antibody [13]. If sites where initial infection might take place are sites accessible to serum IgG then vaccines can prevent infection, but in most cases, vaccines prevent disease by reducing the inoculum, which in turn reduced host damage and the likelihood of disease. In the case of SARS-CoV-2 there is evidence that initial infection and replication 
occurs in the nasal ciliated cells [14], a site that is not accessible to serum IgG unless there is inflammatory damage to the mucosal tissues that allows transudation of serum proteins to the site. Hence, current vaccines for COVID-19 prevent disease but not infection.

\section{How Sterilizing Immunity Works}

Sterilizing immunity requires timely neutralization of the challenging invader by the humoral immune system. This implies that antibodies are usually more relevant than cell-mediated immunity, at least for viruses and microbes where infection can be directly interfered with by specific antibody. On respiratory mucosae, IgA are the most effective antibody class. Secretory $\operatorname{Ig} \mathrm{A}$ (sIgA), consisting of dimeric $\operatorname{Ig} \mathrm{A}$, the J chain, and the secretory component, is secreted from glands (e.g., salivary or mammary) and mucosa-associated lymphoid tissue (MALT) onto mucosae, where it neutralizes pathogens. Of interest, sIgA in pre-pandemic human breast milk [15,16] and saliva [17] cross-react with SARS-CoV-2, but whether such heterologous immunity is protective remains unknown. sIgA, with their short half-life of 6.3 days, also represent a useful biomarker for determining recent SARS-CoV-2 infection. Mucosal immunity is also being exploited for passive immunotherapies. For example, several investigators have proposed edible [18] or intranasal [19] egg-derived IgY for passive immunotherapy, and expression of viral antigens in the leaves of edible plants (e.g., lettuce) is also being investigated to induce immunity [20] Similarly, inhalable bispecific single-domain antibodies neutralize Omicron in a mouse model [21].

\section{Clinically Successful Historical Precedents with Mucosal Vaccines}

Many mucosal surfaces are potential sites for vaccine delivery (e.g., conjunctival, nasal, oral, pulmonary, vaginal, and rectal mucosae); however, logistical and cultural reasons have led researchers to focus mostly on oral, nasal, and pulmonary routes [22]. Respiratory mucosal vaccines offer several practical advantages over traditional vaccination approaches, facilitating mass-vaccination campaigns [23] — increased vaccine stability and shelf-life for dry powdered vaccines, painless delivery using disposable inhalers at home [24] (which reduce the requirements for highly trained health-care personnel), and promise eliciting an immune response including sIgA [23].

Examples of clinically successful mucosal vaccines based on attenuated viruses include oral vaccines for gastrointestinal viruses (poliovirus and rotavirus) and intranasal vaccines for respiratory viruses (influenza virus and adenovirus).

The first successful polio vaccine developed by Jonas Salk in 1955 was inactivated and administered intramuscularly. Like the current COVID-19 vaccines, it reduced the risk of illness, but could not prevent infection. In 1960, Albert Sabin developed an oral polio vaccine using three attenuated strains of poliovirus; this approach has led to almost complete eradication of polio worldwide, with as few as 140 cases reported in 2020 in Pakistan and Afghanistan. Nevertheless, recombination of the attenuated strain with wild poliovirus led to local outbreaks caused by type 2 poliovirus included in the trivalent oral vaccine (so-called vaccine-derived poliovirus (cVDPDV2)), with 1089 cases in 26 countries in 2020. This encouraged, after April 2016, the removal of the strain from the trivalent oral vaccine, and finally the return to inactivated vaccines $[25,26]$.

Oral vaccines for rotavirus have been employed for some time in children, demonstrating high efficacy and safety $[27,28]$.

Intranasal influenza vaccines were first used in the 1960s in the former Soviet Union. Licensed intranasal influenza vaccines for humans exploiting nasopharynx-associated lymphoid tissue (NALT) include FluMist/Fluenz ${ }^{\mathrm{TM}}$ (MedImmune, Gaithersburg, MD, USA) [29] and the Nasovac ${ }^{\mathrm{TM}}$ live attenuated nasal spray manufactured by the Serum Institute of India. The same institute also developed an intranasal, live attenuated influenza virus $A\left(\mathrm{H}_{1} \mathrm{~N}_{1}\right)$, vaccine [30]. None of major flu vaccine manufacturers has engaged with mucosal vaccines yet, so that the majority of flu shots these days are still administered intramuscularly. 
Oral vaccines against wild-type adenovirus serotypes 4 and 7 (Ad4 and Ad7) were developed by the National Institutes of Health (NIH) and the US Department of Defense (DoD) in the 1970s. They were originally co-administered [31,32] and then re-formulated in 2011 [33-37]. Both vaccines have increased safety since they do not disseminate systemically, while inducing systemic serum homotypic $\mathrm{nAb}[34,36,37]$, and providing $>90 \%$ efficacy against illness at 12 weeks [33,34,36,37], which is durable for at least 6 years [38].

Hence, vaccines given by mucosal routes are effective and in clinical use. These vaccines provide important precedents for controlling the COVID-19 pandemic and provide great encouragement that similar vaccines can be deployed against SARS-CoV-2.

\section{IgA Antibodies Play a Key Role in Neutralizing SARS-CoV-2 but Are Rarely Elicited after Intramuscular Vaccination}

Natural SARS-CoV-2 infection usually resolves with the appearance of serum monomeric IgA. In fact, much of the neutralizing activity in convalescent plasma resides in the IgM and IgA fraction $[39,40]$. However, while serum IgG to Spike protein is still present in $92 \%$ of the participants after 7 months, serum $\operatorname{IgA}$ (and $\operatorname{IgM}$ ) antibodies decline rapidly after the first month post onset of disease [41-43].

Dimeric IgA in secretions similarly have a fundamental role in SARS-CoV-2 neutralization [44] —after infection, very high serum IgA levels develop in patients with severe COVID-19-associated acute respiratory distress syndrome (ARDS) [45], and Spike-specific IgA is dominant in human breast milk $[15,16,46]$.

In general, intramuscularly delivered vaccines induce poor mucosal IgA responses. After the first immunization, BNT162b2 induces anti-Spike $\operatorname{IgG}_{1}, \operatorname{IgG}_{3}$, and $\operatorname{Ig} \mathrm{A}_{1}$ (and sometimes $\operatorname{IgG}_{2}$ and $\operatorname{Ig} \mathrm{A}_{2}$ ) in serum, but only $\operatorname{IgG}$ in saliva. One to two weeks after the second dose, IgG levels in saliva and the upper respiratory tract are boosted, while $\operatorname{IgA}$ appear in some subjects [47]. Serum IgA has kinetics of induction and time to peak levels (21 days after first dose and 7-10 days after second dose) that are similar to IgG, but a faster decline $(>23 \%$ reduction from peak at day +80 after first dose) [48].

For human breast milk the isotype profile differs in the antibody response postCOVID-19 and after vaccination. In contrast to natural infection, immunization with mRNA vaccines during lactation increases anti-receptor-binding domain (RBD) IgA levels in milk [49,50], but not in serum [50]. Unfortunately, only $<10 \%$ of milk samples from vaccinees have high IgA endpoint titers, but secretory antibody released in milk is both stable and resistant to enzymatic degradation in neonatal mucosal tissues [3,4].

The paucity of IgA after non-mucosal vaccination suggests that systemically vaccinated patients, while mildly symptomatic or asymptomatic, could still become infected with SARS-CoV-2. There is no conclusive evidence yet as to whether asymptomatically infected vaccinees are infectious since theoretically the virions could be immune-complexed and not infectious [51-54], but the similar viral load seen in NPS from infected vaccinees versus infected naives suggests there is a serious risk of transmission. However, vaccinated individuals who develop symptomatic (e.g., breakthrough) infections are contagious for SARS-CoV-2 [55]. Mild COVID-19 cases in seropositive human vaccinees with positive PCR in different biological matrices (e.g., rectal swab) have also been reported [56], and suggest that the infection in these vaccinees is not limited to the nasopharynx. The case for asymptomatic, vaccinated carriers is of particular concern within hospital settings [8], where patients undergoing clinic and surgical endonasal procedures commonly generate aerosols [57].

Not all systemic vaccines are equally ineffective at inducing mucosal IgA. For example, BNT162b2, but not CoronaVac, induced nasal anti-S1 IgA responses as early as 14 days after the first dose in $72 \%$ of subjects, which persisted for up to 50 days after the second dose in $45 \%$ of subjects [58], and also induced IgA in breastmilk [59]. Nevertheless, IgA levels in mucosae induced by BNT162b2 or mRNA-1273 are low after the first dose, and decline after the second dose. 


\section{Respiratory Delivery of Vaccines Is Needed to Achieve Sterilizing Immunity against SARS-CoV-2}

Animal models involving the related coronaviruses SARS-CoV [60-70] and MERS$\mathrm{CoV}[60,71-74]$ show that mucosal vaccination induces long-lasting systemic and mucosal immunity. Preclinical evidence from studies in rodents (mice, golden hamsters, and ferrets) have been similarly positive for SARS-CoV-2 (reviewed in [23,75-79] and summarized in Table 1), with the caveat that many studies have not yet been peer-reviewed. At least 14 mucosal vaccines have progressed to the first phase of clinical trials as of 14 December 2021 (Table 2), and several could enter the market in 2022.

Routes other than intramuscular could also lead to antigen dose sparing, which can be relevant to relieving manufacturing bottlenecks during pandemics. While this has been proven for the subcutaneous route [80], it has not been formally proven for mucosal routes.

Although we lack formal studies on the efficacy of oral or inhaled vaccines in human subjects lacking parts of the mucosal immune system (e.g., children after removal of the adenoids and tonsils [81], or after appendectomy), it seems reasonable to assume that the remaining mucosal immune system is enough to induce a response from the fact that there is no historical record that these individuals are more susceptible after receiving other types of vaccines.

Table 1. Results of preclinical COVID-19 mucosal vaccines candidates ${ }^{1}$.

\begin{tabular}{|c|c|c|c|c|c|c|}
\hline & Vaccine & Adjuvant & Schedule & $\begin{array}{c}\text { Animal } \\
\text { Model }\end{array}$ & Efficacy & Ref. \\
\hline Live & Live oral & None & $\begin{array}{l}\text { Post-pyloric } \\
\text { administration of } \\
\text { SARS-CoV-2 by } \\
\text { esophagogastroduo- } \\
\text { denoscopy }\end{array}$ & $\begin{array}{l}\text { Rhesus } \\
\text { macaques }\end{array}$ & $\begin{array}{l}\text { Limited virus replication in the } \\
\text { gastrointestinal tract and minimal to no } \\
\text { induction of mucosal antibody titers in } \\
\text { rectal swabs, nasal swabs, or } \\
\text { bronchoalveolar lavage. }\end{array}$ & [82] \\
\hline \multirow{6}{*}{ Subunit } & Recombinant RBD protein & None & Intranasal & Mice & $\begin{array}{l}\text { High titers of serum IgG and nAb as well } \\
\text { as a significant mucosal immunity }\end{array}$ & [83] \\
\hline & $\begin{array}{l}\text { Recombinant RBD protein using } \\
\text { self-assembling Helicobacter } \\
\text { pylori-bullfrog ferritin } \\
\text { nanoparticles, purified from } \\
\text { mammalian cells and assembled } \\
\text { into 24-mer nanoparticles }\end{array}$ & None & Intranasal & Ferrets & $\begin{array}{l}\text { No fever, body weight loss, or clinical } \\
\text { symptoms; rapid clearance of infectious } \\
\text { virus in nasal washes and lungs as well } \\
\text { as of viral RNA in respiratory organs. }\end{array}$ & [84] \\
\hline & \multirow{2}{*}{$\begin{array}{l}\text { RBD }+2 \text { domains of the viral } \\
\text { nucleocapsid protein }(\mathrm{N})\end{array}$} & \multirow{2}{*}{$\begin{array}{l}\text { Heat-labile } \\
\text { enterotoxin B } \\
\text { (LTB) }\end{array}$} & $\begin{array}{l}\text { Three-dose } \\
\text { vaccination } \\
\text { schedule }\end{array}$ & Mice & $\begin{array}{c}\text { Enhanced post-dose- } 3 \mathrm{nAb}, \mathrm{IgG} \text {, and IgA } \\
\text { production to } \mathrm{S}-\text { and } \\
\mathrm{N} \text {-protein-stimulated IFN- } \gamma \text { and IL-2 } \\
\text { secretion by T cells }\end{array}$ & \multirow[t]{2}{*}{85} \\
\hline & & & $\begin{array}{l}\text { Heterologous } \\
\text { subcutaneous prime } \\
\text { with S1 protein and } \\
\text { oral booster }\end{array}$ & Rats & $\begin{array}{l}\text { A single oral booster following two } \\
\text { subcutaneous priming doses elicited } \\
\text { serum IgG and mucosal IgA levels }\end{array}$ & \\
\hline & S1 nanoparticles & $\begin{array}{l}\text { IL-15 and TLR } \\
\text { agonists }\end{array}$ & $\begin{array}{l}\text { IM- } \\
\text { primed/intranasal } \\
\text { (IN)-boosted } \\
\text { mucosal vaccine }\end{array}$ & $\begin{array}{l}\text { Rhesus } \\
\text { macaques }\end{array}$ & $\begin{array}{l}\text { Weaker T-cell and antibody responses, } \\
\text { but higher dimeric IgA and IFNa. No } \\
\text { detectable subgenomic RNA in upper or } \\
\text { lower respiratory tracts }\end{array}$ & [86] \\
\hline & $\begin{array}{l}\text { S1 protein from the beta variant in } \\
\text { PLGA }\end{array}$ & CP15 & $\begin{array}{l}\text { Intranasal after WA } \\
\text { strain priming } 1 \\
\text { year before }\end{array}$ & $\begin{array}{l}\text { Rhesus } \\
\text { macaques }\end{array}$ & $\begin{array}{l}\text { Serum- and bronchoalveolar lavage } \\
\text { (BAL)-IgG, secretory nasal- and } \\
\text { BAL-IgA, and nAb against the original } \\
\text { strain and/or beta variant }\end{array}$ & [87] \\
\hline \multirow{3}{*}{$\begin{array}{l}\text { Virus-like } \\
\text { particles } \\
(\mathrm{VLP})\end{array}$} & $\begin{array}{l}\text { Outer membrane vesicles of } \\
\text { Salmonella typhimurium } \\
\text { conjugated with the mammalian } \\
\text { cell culture-derived RBD } \\
\text { (RBD-OMVs) }\end{array}$ & None & Intranasal & $\begin{array}{l}\text { Golden } \\
\text { Syrian } \\
\text { hamster } \\
\text { (Mesocricetus } \\
\text { auratus) }\end{array}$ & $\begin{array}{l}\text { High titers of blood IgG to RBD as well } \\
\text { as detectable mucosal responses; no } \\
\text { weight loss, lower virus titers in } \\
\text { bronchoalveolar lavage fluid, and less } \\
\text { severe lung pathology. }\end{array}$ & [88] \\
\hline & $\begin{array}{l}\text { VLPs displaying RBD } \\
\text { (CuMVTT-RBD) }\end{array}$ & $\begin{array}{l}\text { Tetanus-toxin; } \\
\text { TLR7/8 } \\
\text { ligands. }\end{array}$ & Intranasal & Mice & $\begin{array}{l}\text { Strong RBD- and spike-specific systemic } \\
\text { IgG and IgA responses of high avidity; } \\
\text { Strong mucosal antibody and plasma cell } \\
\text { production in lung tissue }\end{array}$ & [89] \\
\hline & $\begin{array}{c}\text { Thermostable VLP (e-VLPs) } \\
\text { harnessed with variable surface } \\
\text { proteins (VSPs) from Giardia } \\
\text { lamblia, affording them resistance } \\
\text { to degradation and expressing } \\
\text { pre-fusion stabilized form of S } \\
\text { and membrane protein (M) } \\
\text { expression }\end{array}$ & None & $\begin{array}{l}\text { I.m. prime-oral } \\
\text { boost }\end{array}$ & $\begin{array}{l}\text { Mice and } \\
\text { hamsters }\end{array}$ & $\begin{array}{c}\text { Complete protection from a viral } \\
\text { challenge; dramatically boosted the IgA } \\
\text { mucosal response of intramuscularly } \\
\text { injected vaccines. }\end{array}$ & [90] \\
\hline
\end{tabular}


Table 1. Cont.

\begin{tabular}{|c|c|c|c|c|c|c|}
\hline & Vaccine & Adjuvant & Schedule & $\begin{array}{c}\text { Animal } \\
\text { Model }\end{array}$ & Efficacy & Ref. \\
\hline \multirow{4}{*}{$\begin{array}{l}\text { Adenoviral } \\
\text { vectors }\end{array}$} & Adenovirus type 5 AdCOVID $^{\mathrm{TM}}$ & None & $\begin{array}{c}\text { Single-dose } \\
\text { intranasal }\end{array}$ & Mice & Elicits systemic and mucosal immunity & [91] \\
\hline & Human adenovirus type 5 & None & $\begin{array}{l}\text { Single dose } \\
\text { intranasal }\end{array}$ & $\begin{array}{l}\text { mice and } \\
\text { ferrets }\end{array}$ & $\begin{array}{l}\text { Complete protection in the upper and } \\
\text { lower respiratory tracts. }\end{array}$ & [92] \\
\hline & $\begin{array}{l}\text { Chimpanzee adenovirus encoding } \\
\text { prefusion-stabilized Spike }\end{array}$ & None & $\begin{array}{l}\text { Single dose } \\
\text { intranasal }\end{array}$ & $\begin{array}{l}\text { hACE2 } \\
\text { transgenic } \\
\text { mice }\end{array}$ & $\begin{array}{l}\text { High levels of nAbs, systemic, and } \\
\text { mucosal IgA and T cell responses, and } \\
\text { almost entirely prevents infection in both } \\
\text { the upper and lower respiratory tracts; } \\
\text { durable high nAb and Fc effector } \\
\text { antibody responses in serum and } \\
\text { S-specific IgG and IgA secreting } \\
\text { long-lived plasma cells in the bone } \\
\text { marrow. At } 9 \text { months after vaccination, } \\
\text { serum antibodies neutralized } \\
\text { SARS-CoV-2 strains with B.1.351, } \\
\text { B.1.1.28, and B.1.617.1 spike proteins and } \\
\text { conferred almost complete protection in } \\
\text { the URT and LRT }\end{array}$ & $\begin{array}{l}{[93,} \\
94]\end{array}$ \\
\hline & $\begin{array}{l}\text { Adenovirus } 5 \text { - and 19a-vectored } \\
\text { vaccines }\end{array}$ & None & $\begin{array}{c}\text { Intranasal } \\
\text { vaccinations with } \\
\text { adenovirus 5- and } \\
\text { 19a-vectored } \\
\text { vaccines following a } \\
\text { systemic DNA or } \\
\text { mRNA priming }\end{array}$ & Mice & $\begin{array}{l}\text { Strong systemic and mucosal immunity; } \\
\text { high levels of IgA and tissue-resident } \\
\text { memory T cells in the respiratory tract. } \\
\text { Mucosal neutralization of VOC was also } \\
\text { enhanced. Importantly, priming with } \\
\text { mRNA provoked a more comprehensive } \\
\text { T cell response consisting of circulating } \\
\text { and tissue-resident memory T cells after } \\
\text { the boost, while a DNA priming induced } \\
\text { mostly mucosal T cells. }\end{array}$ & [95] \\
\hline \multirow[b]{2}{*}{$\begin{array}{l}\text { vaccinia } \\
\text { vectors }\end{array}$} & $\begin{array}{c}\text { Mucosal homologous plasmid } \\
\text { and a heterologous immunization } \\
\text { strategy using a plasmid vaccine } \\
\text { and a Modified Vaccinia Ankara } \\
\text { (MVA) expressing Spike (S) and } \\
\text { nucleocapsid (N) antigens. }\end{array}$ & None & Mucosal & Mice & $\begin{array}{l}\text { nAb in serum and bronchoalveolar } \\
\text { lavage; induction of Th1 and Th17 } \\
\text { responses and polyfunctional T-cells } \\
\text { expressing multiple type- } 1 \text { cytokines } \\
\text { (e.g., IFN- } \gamma, \text { TNF } \alpha \text {, and IL-2) in the } \\
\text { lungs and spleen }\end{array}$ & [96] \\
\hline & $\begin{array}{l}\text { Pre-fusion-stabilized Washington } \\
\text { strain Spike, expressed from a } \\
\text { highly attenuated, } \\
\text { replication-competent vaccinia } \\
\text { virus construct, NYVAC-KC. }\end{array}$ & None & Intranasal & Mice & $\begin{array}{c}\text { Fully protected against disease and death } \\
\text { from the mouse-adapted strain of } \\
\text { SARS-CoV-2, SARS2-N501YMA30, } \\
\text { contains a spike that is also heavily } \\
\text { mutated, with mutations at four of the } \\
\text { five positions in the Omicron spike } \\
\text { associated with neutralizing antibody } \\
\text { escape (K417, E484, Q493, and N501). }\end{array}$ & [97] \\
\hline $\begin{array}{l}\text { Lentiviral } \\
\text { vectors }\end{array}$ & Spike & None & $\begin{array}{c}\text { Systemic } \\
\text { prime-intranasal } \\
\text { boost }\end{array}$ & $\begin{array}{l}\text { hACE2 } \\
\text { transgenic } \\
\text { mice and } \\
\text { golden } \\
\text { hamsters }\end{array}$ & $\begin{array}{l}>3 \log _{10} \text { decrease in the lung viral loads } \\
\text { and reduces local inflammation }\end{array}$ & [98] \\
\hline $\begin{array}{l}\text { Rhabdoviral } \\
\text { vectors }\end{array}$ & $\begin{array}{l}\text { VSV-SARS2 }(+G) \text { virions } \\
\text { generated by } G \text { protein } \\
\text { trans-complementation }\end{array}$ & None & Oral & $\begin{array}{l}\text { Cynomolgus } \\
\text { macaques }\end{array}$ & $\begin{array}{l}\text { Compared to parental VSV-SARS2, } \\
\text { G-supplemented viruses were orally } \\
\text { active in virus-naive and vaccine-primed } \\
\text { cynomolgus macaques, powerfully } \\
\text { boosting SARS-CoV-2 nAb titers }\end{array}$ & [99] \\
\hline $\begin{array}{l}\text { Live } \\
\text { attenuated } \\
\text { influenza } \\
\text { virus } \\
\text { vectors }\end{array}$ & $\begin{array}{l}\text { LAIV-CA4-RBD } \\
\text { LAIV-HK68-RBD }\end{array}$ & None & $\begin{array}{c}\text { Systemic } \\
\text { prime-intranasal } \\
\text { boost }\end{array}$ & $\begin{array}{l}\text { K18-hACE2 } \\
\text { mice }\end{array}$ & $\begin{array}{c}\text { Higher systemic and mucosal immune } \\
\text { responses, including bronchoalveolar } \\
\text { lavage IgA/IgG and lung polyfunctional } \\
\text { memory CD8 T cells, including against } \\
\text { VOC }\end{array}$ & [100] \\
\hline
\end{tabular}

${ }^{1}$ Wording in many of the table cells was taken verbatim from the cited reference to maintain the exact meaning as in the original report.

Table 2. Candidate COVID-19 mucosal vaccines in clinical trials and development progress.

\begin{tabular}{cccccccc}
\hline Country & Company & Vaccine Name & Technology & $\begin{array}{c}\text { Delivery } \\
\text { Route }\end{array}$ & Schedule & $\begin{array}{c}\text { Development } \\
\text { Progress }\end{array}$ & $\begin{array}{c}\text { NCT } \\
\text { Identifier }\end{array}$ \\
\hline USA & Altimmune & AdCOVID ${ }^{\mathrm{TM}}$ & $\begin{array}{c}\text { Replication- } \\
\text { deficient } \\
\text { adenovirus 5 } \\
\text { (RD-Ad5) }\end{array}$ & Intranasal & $\begin{array}{c}\text { Single or } \\
\text { two-dose } \\
\text { intranasal }\end{array}$ & $\begin{array}{c}\text { Phase I } \\
\text { (randomized) }\end{array}$ & NCT04679909 \\
\hline
\end{tabular}


Table 2. Cont.

\begin{tabular}{|c|c|c|c|c|c|c|c|}
\hline Country & Company & Vaccine Name & Technology & $\begin{array}{l}\text { Delivery } \\
\text { Route }\end{array}$ & Schedule & $\begin{array}{l}\text { Development } \\
\text { Progress }\end{array}$ & $\begin{array}{l}\text { NCT } \\
\text { Identifier }\end{array}$ \\
\hline Australia & $\begin{array}{l}\text { Tetherex Phar- } \\
\text { maceuticals } \\
\text { Corporation }\end{array}$ & SC-Ad6-1 & $\begin{array}{c}\text { Adenovirus type } \\
6\end{array}$ & Intranasal & $\begin{array}{c}\text { Single or } \\
\text { multiple doses }\end{array}$ & Phase I & NCT04839042 \\
\hline USA-India & $\begin{array}{l}\text { University of } \\
\text { Wisconsin- } \\
\text { Madison, } \\
\text { FluGen and } \\
\text { Bharat Biotech }\end{array}$ & $\begin{array}{c}\text { BBV154 } \\
\left(\text { CoroFlu }^{\mathrm{TM}}\right)\end{array}$ & $\begin{array}{c}\text { M2-deficient, } \\
\text { single replication } \\
\text { (M2SR) influenza } \\
\text { virus vector }\end{array}$ & Intranasal & Two doses & $\begin{array}{c}\text { Phase I } \\
\text { (randomized) }\end{array}$ & NCT04751682 \\
\hline \multirow[t]{2}{*}{ USA } & $\begin{array}{l}\text { ImmunityBio, } \\
\text { Inc. }\end{array}$ & $\begin{array}{l}\text { hAd5-S-Fusion } \\
\text { + N-ETSD }\end{array}$ & $\begin{array}{l}\text { Full-length } \mathrm{S} \text { and } \\
\mathrm{N}+\text { enhanced } \\
\text { T-cell stimulation } \\
\text { domain (ETSD) }\end{array}$ & $\begin{array}{l}\text { Subcutaneous, } \\
\text { sublingual, } \\
\text { and oral } \\
\text { (capsule) }\end{array}$ & Single dose & $\begin{array}{c}\text { Phase I/II } \\
\text { (randomized) }\end{array}$ & $\begin{array}{c}\text { NCT04732468 } \\
\text { NCT04845191 } \\
\text { NCT04591717 } \\
\text { [101] }\end{array}$ \\
\hline & Vaxart Inc. & VXA-CoV2-1 & $\begin{array}{l}\text { Non-replicating } \\
\text { Ad5 encoding } \\
\text { Spike [102] }\end{array}$ & Oral tablet & $\begin{array}{l}\text { One or two } \\
\text { doses }\end{array}$ & $\begin{array}{c}\text { Phase II } \\
\text { (randomized) }\end{array}$ & $\begin{array}{l}\text { NCT04563702 } \\
\text { NCT05067933 }\end{array}$ \\
\hline China & $\begin{array}{c}\text { Institute of } \\
\text { Biotechnology, } \\
\text { Academy of } \\
\text { Military } \\
\text { Medical } \\
\text { Sciences, PLA } \\
\text { of China }\end{array}$ & Ad5-nCoV & Ad5-nCoV & $\begin{array}{l}\text { I.m. prime, } \\
\text { intranasal } \\
\text { boost }\end{array}$ & Two doses & $\begin{array}{c}\text { Phase I } \\
\text { (randomized) }\end{array}$ & $\begin{array}{c}\text { NCT04552366 } \\
\text { [103] }\end{array}$ \\
\hline Mexico & $\begin{array}{c}\text { Laboratorio } \\
\text { Avi-Mex, S.A. } \\
\text { de C.V. }\end{array}$ & n.a. & $\begin{array}{c}\text { Recombinant } \\
\text { Newcastle } \\
\text { disease virus } \\
\text { (NDV) vectored } \\
\text { vaccine }\end{array}$ & $\begin{array}{l}\text { Intranasal } \\
\text { prime-i.m. } \\
\text { boost }\end{array}$ & Two doses & Phase I & NCT04871737 \\
\hline UK & Codagenix & COVI-VAC & $\begin{array}{l}\text { Live-attenuated } \\
\text { virus }\end{array}$ & Intranasal & $\begin{array}{l}\text { Single or two } \\
\text { doses }\end{array}$ & $\begin{array}{c}\text { Phase I } \\
\text { (randomized) }\end{array}$ & NCT04619628 \\
\hline UK & $\begin{array}{l}\text { University of } \\
\text { Oxford }\end{array}$ & $\begin{array}{l}\text { ChAdOx1 } \\
\text { nCov-19 }\end{array}$ & $\begin{array}{c}\text { Chimpanzee } \\
\text { adenovirus } \\
\text { expressing Spike } \\
\text { RBD }\end{array}$ & Intranasal & Single dose & Phase I & NCT04816019 \\
\hline USA & CyanVac LLC & CVXGA1-001 & $\begin{array}{c}\text { Parainfluenza } \\
\text { virus } 5 \\
\text { (PIV5)-vectored } \\
\text { expressing } \\
\text { SARS-CoV-2 } \\
\text { Spike }\end{array}$ & Intranasal & Single dose & Phase I & NCT04954287 \\
\hline USA & $\begin{array}{c}\text { Meissa } \\
\text { Vaccines, Inc }\end{array}$ & MV-014-212 & $\begin{array}{c}\text { Live attenuated } \\
\text { vaccine against } \\
\text { RSV expressing } \\
\text { Spike of } \\
\text { SARS-CoV-2. }\end{array}$ & Intranasal & $\begin{array}{l}\text { Single or two } \\
\text { doses }\end{array}$ & Phase I & NCT04798001 \\
\hline USA & $\begin{array}{l}\text { Symvivo } \\
\text { Corporation }\end{array}$ & bacTRL-Spike & $\begin{array}{c}\text { Live } \\
\text { Bifidobacterium } \\
\text { longum, } \\
\text { delivering } \\
\text { plasmids } \\
\text { encoding Spike }\end{array}$ & Oral & Single dose & Phase I & NCT04334980 \\
\hline $\begin{array}{l}\text { New } \\
\text { Zealand- } \\
\text { USA }\end{array}$ & $\begin{array}{l}\text { Syneos Health- } \\
\text { VaxForm } \\
\text { LLC }\end{array}$ & CoV2-OGEN1 & n.a. & $\begin{array}{c}\text { Oral } \\
\text { suspension }\end{array}$ & Single dose & phase I & NCT04893512 \\
\hline Hong Kong & $\begin{array}{l}\text { University of } \\
\text { Hong Kong }\end{array}$ & $\begin{array}{c}\text { DelNS1-nCoV- } \\
\text { RBD } \\
\text { LAIV }\end{array}$ & $\begin{array}{l}\text { Live attenuated } \\
\text { influenza virus } \\
\text { expressing Spike } \\
\text { RBD }\end{array}$ & Intranasal & Single dose & Phase I & $\begin{array}{l}\text { NCT04809389 } \\
\text { ChiCTR2000037782 }\end{array}$ \\
\hline
\end{tabular}




\section{Sterilizing Immunity and the Future of SARS-CoV-2 Virulence}

In the case of a vaccine not inducing sterilizing immunity, ongoing transmission is expected to facilitate attenuation to human hosts, although experiences with such "leaky" vaccines in farmed animals have not been conclusive. For example, using Marek disease virus (MDV) in chickens, nonsterilizing vaccines may increase [104] or decrease [105] virulence. Generally, the more a virus circulates, the better should be its adaptation to the host. Evolutionary models suggest that trade-off between virulence and transmissivity maximizes pathogen fitness while reducing virulence, but it is unclear whether this is a universal phenomenon for all viruses [106]. In fact, much depends on the relationship between virulence and transmissibility and the cost of virulence for the microbe in question [107]. For organisms that require virulence for transmission to a new host the capacity for pathogenicity is essential to their survival and attenuation should not necessarily be expected [107]). For SARS-CoV-2 we already know that asymptomatic spread is possible, implying that virulence is not essential for transmissibility. The rapidity of attenuation (decades to millions of years) stems from variables such as lethality and transmission efficiency, making it impossible to draw predictions. While attenuation with circulation among humans is not a universal trajectory, in the past many respiratory viruses have spontaneously attenuated in time, including coronaviruses (e.g., OC-43, which evolved from the causal agent of the 1885-1894 Russian flu pandemic [108] to the virus currently causing common flu). Evidence of mild spontaneous attenuation of human viruses also comes more RNA viruses (e.g., influenza virus A(H1N1) [109,110], dengue virus type 2 [111], and Ebolavirus, from HIV [112,113], although such pathogens are far from being avirulent. The ongoing SARS-CoV-2 pandemic was an unprecedented opportunity to monitor reproductive numbers $\left(R_{t}\right)$ in real-time, and we observed an increase from 1.2 for the original Wuhan strain to 4.0 for the current Delta-plus variant of concern (VOC) [114]: in other words, more virulent and less transmissive variants were rapidly replaced by more transmissive and less virulent variants. Currently, the evolutive process is ongoing with more than 170 Delta sublineages competing each other [115] and another VOC, dubbed Omicron, recently reported [116,117]. Given the increasing spread of attenuated SARS-CoV-2 strains from asymptomatic carriers during lockdown periods, competition of attenuated SARS-CoV-2 strains with the non-attenuated ones has been hypothesized to contribute towards reducing overall virulence [118]. Attenuated viral strains have been a pillar of immunization campaigns for decades, and their intended circulation should not be underestimated.

On the other hand, vaccines causing sterilizing immunity in humans come with the additional risk of preventing spontaneous attenuation by abrogating viral replication and evolution thus pushing the virus into animal reservoirs, where it remains a zoonosis with the possibility of reintroduction into human populations with variants with increased morbidity and lethality (back-adaptation). SARS-CoV-2 is a panzootic virus, and, of interest, all the four current VOCs are able to completely overcome the former Spike restriction for mouse ACE2, and individual VOCs show higher affinities for rat, ferret, and civet ACE2 receptors thanks to N501Y and E484K substitutions in the RBD of Spike.

That said, increased circulation comes with the serious risk of an attenuated lineage reverting to a more virulent one, via single nucleotide mutations, deletions, or recombination. Multiple coronavirus subgenera have a tendency for recombination in low GC genome regions, non-coding regions, edges of genes, and nondisruptive Spike sites [119]. For SARS-CoV-2, two recombinant lineages are already in circulation (XA and XB).

Furthermore, RNA viruses are extremely prone to mutation, exposing them to socalled "lethal mutagenesis" [120], which has been supposed to have caused the sudden disappearance of SARS-CoV-1 [121]. With SARS-CoV-2, this hypothesis has been used recently to explain sudden reduction in incidence of the Delta VOC in Japan [114], but competition from more fit sublineages remains an alternative explanation. Hence, both sterilizing and non-sterilizing vaccines are likely to have a major impact on the course of 
SARS-CoV-2 virulence evolution for humans, which could pose new future challenges as humanity continues to confront the threat from this virus.

\section{The Challenge of Vaccine Non-Responders}

As with any social need, a compromise is often required between the unmet needs of the vulnerable individuals and the general safety to the immunocompetent population. Poor vaccine responses, persisting after three doses, remain a serious problem for immunocompromised patients [122]. These individuals remain at risk for infection and disease and represent a significant population given the success of modern medicine to treat many oncologic and rheumatologic conditions with therapies that impair immunity. Hence, the problem of non-vaccine-responding immunosuppressed individuals is likely to complicate any efforts to contain or end the pandemic as these hosts remain vulnerable to SARS-CoV-2 and, by replicating the virus for long times, represent an ideal landscape for emergence of viral variants. Prophylaxis with passive immunotherapies is nowadays feasible with s.c. mAbs cocktails (including long-acting antibodies), i.m. hyperimmune sera, or i.v. convalescent plasma. While RCTs are ongoing, there is huge rationale for expecting efficacy from such pre-exposure prophylaxis.

\section{Are Systemic COVID-19 Vaccines Just "Selfish" Vaccines?}

Systemic vaccines unable to provide herd immunity are recognized as "selfish" by generalist press, i.e., they are considered beneficial exclusively for the vaccinee themselves, who is spared from severe disease. Actually, this is a misperception given the obvious social benefits from reduced COVID-19 mortality and morbidity and hospital decongestion, the benefits of systemic vaccines go far beyond the mitigation of COVID-19 course. For example, a shorter duration of viral shedding in NPS (despite peak loads largely similar to unvaccinated cases) leads to reduction of community transmission and to lower probability of within-host mutations. On a wider perspective, the heterogeneity of the SARS-CoV-2 lineages is inversely correlated with rate of vaccination (specifically demonstrated for the Delta VOC on an individual perspective, viral isolates recovered from vaccine breakthrough patients show 2.3-fold lower diversity in known SARS-CoV-2 B cell epitopes in comparison to unvaccinated COVID-19 patients [123]. Hence, the vaccines are already potentially taking a biological toll on viral fitness by reducing its genetic diversity.

\section{Conclusions}

Vaccines remains the best hope for ending the COVID-19 pandemic and reducing mortality. The development of several effective vaccines within the first year of the pandemic was a remarkable accomplishment. Mucosal vaccines were not the primary/first approach taken with SARS-CoV-2 because at the beginning of the pandemic we had poor knowledge of how sterilizing immunity worked against coronaviruses. Nevertheless, vaccines that elicit systemic immunity without mucosal immunity are unlikely to end the pandemic because these prevent disease and not infection, and every case of infection involves viral replication with the opportunity for the emergence of vaccine-resistant variants. Every preventive or therapeutic human intervention against a pathogen creates selective pressure that can lead to the emergence of escape variants [124] and vaccines are no exception. This may apply to competition among lineages as well as accelerated intra-vaccinee evolution. The situation with COVID-19 calls for continued research in vaccine development and given the extent of the global calamity brought by SARS-CoV-2 we anticipate the need for, and development of, a new generation of vaccines that elicit mucosal immunity against multiple viral antigens. Further studies combining post-vaccination monitoring and genetic sequencing of SARS-CoV-2-positive cases are warranted to clarify the effects of altering the natural viral evolution with vaccination campaigns.

Funding: This research received no external funding.

Institutional Review Board Statement: Not applicable. 
Informed Consent Statement: Not applicable.

Data Availability Statement: Data available in a publicly accessible repositories.

Conflicts of Interest: D.F. received fees for the advisory board by Novavax. The other authors declare no conflict of interest related to this manuscript.

\section{References}

1. Ewer, K.J.; Barrett, J.R.; Belij-Rammerstorfer, S.; Sharpe, H.; Makinson, R.; Morter, R.; Flaxman, A.; Wright, D.; Bellamy, D.; Bittaye, M.; et al. T cell and antibody responses induced by a single dose of ChAdOx1 nCoV-19 (AZD1222) vaccine in a phase $1 / 2$ clinical trial. Nat. Med. 2021, 27, 270-278. [CrossRef]

2. Hart, T.K.; Cook, R.M.; Zia-Amirhosseini, P.; Minthorn, E.; Sellers, T.S.; Maleeff, B.E.; Eustis, S.; Schwartz, L.W.; Tsui, P.; Appelbaum, E.R.; et al. Preclinical efficacy and safety of mepolizumab (SB-240563), a humanized monoclonal antibody to IL-5, in cynomolgus monkeys. J. Allergy Clin. Immunol. 2001, 108, 250-257. [CrossRef]

3. Peebles, R.S., Jr.; Liu, M.C.; Lichtenstein, L.M.; Hamilton, R.G. IgA, IgG and IgM quantification in bronchoalveolar lavage fluids from allergic rhinitics, allergic asthmatics, and normal subjects by monoclonal antibody-based immunoenzymetric assays. J. Immunol. Methods 1995, 179, 77-86. [CrossRef]

4. Wu, H.; Pfarr, D.S.; Johnson, S.; Brewah, Y.A.; Woods, R.M.; Patel, N.K.; White, W.I.; Young, J.F.; Kiener, P.A. Development of motavizumab, an ultra-potent antibody for the prevention of respiratory syncytial virus infection in the upper and lower respiratory tract. J. Mol. Biol. 2007, 368, 652-665. [CrossRef]

5. Borrok, M.J.; DiGiandomenico, A.; Beyaz, N.; Marchetti, G.M.; Barnes, A.S.; Lekstrom, K.J.; Phipps, S.S.; McCarthy, M.P.; Wu, H.; Dall'Acqua, W.F.; et al. Enhancing IgG distribution to lung mucosal tissue improves protective effect of anti-pseudomonas aeruginosa antibodies. JCI Insight 2018, 3, e97844. [CrossRef] [PubMed]

6. Piano Mortari, E.; Russo, C.; Vinci, M.R.; Terreri, S.; Fernandez Salinas, A.; Piccioni, L.; Alteri, C.; Colagrossi, L.; Coltella, L.; Ranno, S.; et al. Highly-specific memory B cells generation after the 2nd dose of BNT162b2 vaccine compensate for the decline of serum antibodies and absence of mucosal IgA. Cells 2021, 10, 2541. [CrossRef] [PubMed]

7. Oran, D.; Topol, E. The proportion of SARS-CoV-2 infections that are asymptomatic. Ann. Intern. Med. 2021, 174, 1344-1345. [CrossRef] [PubMed]

8. Novazzi, F.; Taborelli, S.; Baj, A.; Focosi, D.; Maggi, F. Asymptomatic SARS-CoV-2 vaccine breakthrough infections in health care workers identified through routine universal surveillance testing. Ann. Intern. Med. 2021, 174, 1770-1772. [CrossRef] [PubMed]

9. Kennedy-Shaffer, L.; Kahn, R.; Lipsitch, M. Estimating vaccine efficacy against transmission via effect on viral load. Epidemiology 2021, 32, 820-828. [CrossRef]

10. Zhou, D.; Chan, J.F.-W.; Zhou, B.; Zhou, R.; Li, S.; Shan, S.; Liu, L.; Zhang, A.J.; Chen, S.J.; Chan, C.C.-S.; et al. Robust SARS-CoV-2 infection in nasal turbinates after treatment with systemic neutralizing antibodies. Cell Host Microbe 2021, 29, 551-563.e555. [CrossRef] [PubMed]

11. Halwe, S.; Kupke, A.; Vanshylla, K.; Liberta, F.; Gruell, H.; Zehner, M.; Rohde, C.; Kraehling, V.; Gellhorn-Serra, M.; Kreer, C.; et al. Intranasal administration of a monoclonal neutralizing antibody protects mice against SARS-CoV-2 infection. Viruses 2021, 13, 1498. [CrossRef]

12. Casadevall, A.; Pirofski, L.A. Host-pathogen interactions: Redefining the basic concepts of virulence and pathogenicity. Infect. Immun. 1999, 67, 3703-3713. [CrossRef]

13. Robbins, J.B.; Schneerson, R.; Szu, S.C. Perspective: Hypothesis: Serum IgG antibody is sufficient to confer protection against infectious diseases by inactivating the inoculum. J. Infect. Dis. 1995, 171, 1387-1398. [CrossRef]

14. Ahn, J.H.; Kim, J.; Hong, S.P.; Choi, S.Y.; Yang, M.J.; Ju, Y.S.; Kim, Y.T.; Kim, H.M.; Rahman, M.D.T.; Chung, M.K.; et al. Nasal ciliated cells are primary targets for SARS-CoV-2 replication in the early stage of COVID-19. J. Clin. Investig. 2021, 131, e148517. [CrossRef]

15. Fox, A.; Marino, J.; Amanat, F.; Krammer, F.; Hahn-Holbrook, J.; Zolla-Pazner, S.; Powell, R.L. Robust and specific secretory IgA against SARS-CoV-2 detected in human milk. iScience 2020, 23, 101735. [CrossRef] [PubMed]

16. Demers-Mathieu, V.; Do, D.M.; Mathijssen, G.B.; Sela, D.A.; Seppo, A.; Järvinen, K.M.; Medo, E. Difference in levels of SARS-CoV-2 S1 and S2 subunits- and nucleocapsid protein-reactive SIgM/IgM, IgG and SIgA/IgA antibodies in human milk. J. Perinatol. Off. J. Calif. Perinat. Assoc. 2020, 1, 1-10. [CrossRef]

17. Tsukinoki, K.; Yamamoto, T.; Handa, K.; Iwamiya, M.; Ino, S.; Sakurai, T. Detection of cross-reactive IgA in saliva against SARS-CoV-2 Spike1 subunit. PLoS ONE 2021, 16, e0249979. [CrossRef] [PubMed]

18. Kadiyala, G.; Iyer, S.; Meher, K.; Vangala, S.; Chandran, S.; Saxena, U. Preparation of ingestible antibodies to neutralize the binding of SarsCoV2 RBD (receptor binding domain) to human ACE2 Receptor. bioRxiv 2021. [CrossRef]

19. Frumkin, L.R.; Lucas, M.; Scribner, C.L.; Ortega-Heinly, N.; Rogers, J.; Yin, G.; Hallam, T.J.; Yam, A.; Bedard, K.; Begley, R.; et al. Egg-derived anti-SARS-CoV-2 immunoglobulin Y (IgY) with broad variant activity as intranasal prophylaxis against COVID-19: Preclinical studies and randomized controlled phase 1 clinical trial. medRxiv 2022. [CrossRef]

20. Power, M.; Azad, T.; Bell, J.C.; MacLean, A. Plant-based expression of SARS-CoV-2 antigens for use in an oral vaccine. bioRxiv 2021. [CrossRef] 
21. Li, C.; Zhan, W.; Yang, Z.; Tu, C.; Zhu, Y.; Song, W.; Huang, K.; Gu, X.; Kong, Y.; Zhang, X.; et al. Broad neutralization of SARS-CoV-2 variants by an inhalable bispecific single-domain antibody. bioRxiv 2021. [CrossRef]

22. Yusuf, H.; Kett, V. Current prospects and future challenges for nasal vaccine delivery. Hum. Vaccines Immunother. 2017, 13, 34-45. [CrossRef] [PubMed]

23. Heida, R.; Hinrichs, W.L.; Frijlink, H.W. Inhaled vaccine delivery in the combat against respiratory viruses: A 2021 overview of recent developments and implications for COVID-19. Expert Rev. Vaccines 2021, 1-18. [CrossRef]

24. Jhaveri, R.; Allyne, K. A feasibility trial of home administration of intranasal vaccine by parents to eligible children. Clin. Ther. 2017, 39, 204-211. [CrossRef] [PubMed]

25. Bandyopadhyay, A.S.; Garon, J.; Seib, K.; Orenstein, W.A. Polio vaccination: Past, present and future. Future Microbiol. 2015, 10, 791-808. [CrossRef] [PubMed]

26. Jain, S.; P, B.; Singh, S.; Singla, A.; Kundu, H.; Singh, K. Polio eradication-lessons from the past and future perspective. J. Clin. Diagn. Res. JCDR 2014, 8, Zc56-Zc60. [CrossRef]

27. Kirkwood, C.D.; Ma, L.F.; Carey, M.E.; Steele, A.D. The rotavirus vaccine development pipeline. Vaccine 2019, 37, 7328-7335. [CrossRef]

28. Glass, R.I.; Parashar, U.D.; Bresee, J.S.; Turcios, R.; Fischer, T.K.; Widdowson, M.A.; Jiang, B.; Gentsch, J.R. Rotavirus vaccines: Current prospects and future challenges. Lancet 2006, 368, 323-332. [CrossRef]

29. Carter, N.J.; Curran, M.P. Live attenuated influenza vaccine (FluMist ${ }^{\circledR} ;$ Fluenz $^{\mathrm{TM}}$ ): A review of its use in the prevention of seasonal influenza in children and adults. Drugs 2011, 71, 1591-1622. [CrossRef]

30. Watts, P.J.; Smith, A. Re-formulating drugs and vaccines for intranasal delivery: Maximum benefits for minimum risks? Drug Discov. Today 2011, 16, 4-7. [CrossRef]

31. Top, F.H., Jr.; Grossman, R.A.; Bartelloni, P.J.; Segal, H.E.; Dudding, B.A.; Russell, P.K.; Buescher, E.L. Immunization with live types 7 and 4 adenovirus vaccines. I. Safety, infectivity, antigenicity, and potency of adenovirus type 7 vaccine in humans. J. Infect. Dis. 1971, 124, 148-154. [CrossRef] [PubMed]

32. Top, F.H., Jr.; Dudding, B.A.; Russell, P.K.; Buescher, E.L. Control of respiratory disease in recruits with types 4 and 7 adenovirus vaccines. Am. J. Epidemiol. 1971, 94, 142-146. [CrossRef]

33. Kuschner, R.A.; Russell, K.L.; Abuja, M.; Bauer, K.M.; Faix, D.J.; Hait, H.; Henrick, J.; Jacobs, M.; Liss, A.; Lynch, J.A.; et al. A phase 3, randomized, double-blind, placebo-controlled study of the safety and efficacy of the live, oral adenovirus type 4 and type 7 vaccine, in U.S. military recruits. Vaccine 2013, 31, 2963-2971. [CrossRef] [PubMed]

34. Lyons, A.; Longfield, J.; Kuschner, R.; Straight, T.; Binn, L.; Seriwatana, J.; Reitstetter, R.; Froh, I.B.; Craft, D.; McNabb, K.; et al. A double-blind, placebo-controlled study of the safety and immunogenicity of live, oral type 4 and type 7 adenovirus vaccines in adults. Vaccine 2008, 26, 2890-2898. [CrossRef]

35. Choudhry, A.; Mathena, J.; Albano, J.D.; Yacovone, M.; Collins, L. Safety evaluation of adenovirus type 4 and type 7 vaccine live, oral in military recruits. Vaccine 2016, 34, 4558-4564. [CrossRef]

36. Gaydos, C.A.; Gaydos, J.C. Adenovirus vaccines in the U.S. military. Mil. Med. 1995, 160, 300-304. [CrossRef]

37. Hilleman, M.R.; Stallones, R.A.; Gauld, R.L.; Warfield, M.S.; Anderson, S.A. Vaccination against acute respiratory illness of adenovirus (RI-APC-ARD) etiology. Am. J. Public Health Nation's Health 1957, 47, 841-847. [CrossRef] [PubMed]

38. Collins, N.D.; Adhikari, A.; Yang, Y.; Kuschner, R.A.; Karasavvas, N.; Binn, L.N.; Walls, S.D.; Graf, P.C.F.; Myers, C.A.; Jarman, R.G.; et al. Live oral adenovirus type 4 and type 7 vaccine induces durable antibody response. Vaccines 2020, 8, 411. [CrossRef] [PubMed]

39. Gasser, R.; Cloutier, M.; Prevost, J.; Fink, C.; Ducas, E.; Ding, S.; Dussault, N.; Landry, P.; Tremblay, T.; Laforce-Lavoie, A.; et al. Major role of IgM in the neutralizing activity of convalescent plasma against SARS-CoV-2. Cell Rep. 2020, 34, 108790. [CrossRef] [PubMed]

40. Verkerke, H.; Saeedi, B.J.; Boyer, D.; Allen, J.W.; Owens, J.; Shin, S.; Horwath, M.; Patel, K.; Paul, A.; Wu, S.C.; et al. Are we forgetting about IgA? A re-examination of coronavirus disease 2019 convalescent plasma. Transfusion 2021, 61, 1740-1748. [CrossRef] [PubMed]

41. den Hartog, G.; Vos, E.R.A.; van den Hoogen, L.L.; van Boven, M.; Schepp, R.M.; Smits, G.; van Vliet, J.; Woudstra, L.; WijmengaMonsuur, A.J.; van Hagen, C.C.E.; et al. Persistence of antibodies to SARS-CoV-2 in relation to symptoms in a nationwide prospective study. Clin. Infect. Dis. 2021, 73, 2155-2162. [CrossRef]

42. Klingler, J.; Weiss, S.; Itri, V.; Liu, X.; Oguntuyo, K.Y.; Stevens, C.; Ikegame, S.; Hung, C.-T.; Enyindah-Asonye, G.; Amanat, F.; et al. Role of IgM and IgA antibodies in the neutralization of SARS-CoV-2. J. Infect. Dis. 2020, 223, 957-970. [CrossRef]

43. Sterlin, D.; Mathian, A.; Miyara, M.; Mohr, A.; Anna, F.; Claer, L.; Quentric, P.; Fadlallah, J.; Ghillani, P.; Gunn, C.; et al. IgA dominates the early neutralizing antibody response to SARS-CoV-2. Sci. Transl. Med. 2021, 13, 2223. [CrossRef] [PubMed]

44. Wang, Z.; Lorenzi, J.C.C.; Muecksch, F.; Finkin, S.; Viant, C.; Gaebler, C.; Cipolla, M.; Hoffmann, H.H.; Oliveira, T.Y.; Oren, D.A.; et al. Enhanced SARS-CoV-2 neutralization by dimeric IgA. Sci. Transl. Med. 2021, 13, eabf1555. [CrossRef] [PubMed]

45. Cervia, C.; Nilsson, J.; Zurbuchen, Y.; Valaperti, A.; Schreiner, J.; Wolfensberger, A.; Raeber, M.E.; Adamo, S.; Weigang, S.; Emmenegger, M.; et al. Systemic and mucosal antibody responses specific to SARS-CoV-2 during mild versus severe COVID-19. J. Allergy Clin. Immunol. 2020, 147, 545-557.e549. [CrossRef] [PubMed] 
46. Fox, A.; Marino, J.; Amanat, F.; Oguntuyo, K.; Hahn-Holbrook, J.; Lee, B.; Krammer, F.; Zolla-Pazner, S.; Powell, R.L. The spike-specific IgA in milk commonly-elicited after SARS-CoV-2 infection is concurrent with a robust secretory antibody response, exhibits neutralization potency strongly correlated with IgA binding, and is highly durable over time. medRxiv 2021. [CrossRef]

47. Ketas, T.J.; Chaturbhuj, D.; Cruz-Portillo, V.M.; Francomano, E.; Golden, E.; Chandrasekhar, S.; Debnath, G.; Diaz-Tapia, R.; Yasmeen, A.; Leconet, W.; et al. Antibody responses to SARS-CoV-2 mRNA vaccines are detectable in saliva. Pathog. Immun. 2021, 6, 116-134. [CrossRef]

48. Wisnewski, A.V.; Campillo-Luna, J.; Redlich, C.A. Human IgG and IgA responses to COVID-19 mRNA vaccines. PLoS ONE 2021, 16, e0249499. [CrossRef]

49. Baird, J.K.; Jensen, S.M.; Urba, W.J.; Fox, B.A.; Baird, J.R. SARS-CoV-2 antibodies detected in mother's milk post-vaccination. J. Hum. Lact. 2021, 37, 492-498. [CrossRef]

50. Gray, K.J.; Bordt, E.A.; Atyeo, C.; Deriso, E.; Akinwunmi, B.; Young, N.; Baez, A.M.; Shook, L.L.; Cvrk, D.; James, K.; et al COVID-19 vaccine response in pregnant and lactating women: A cohort study. Am. J. Obstet. Gynecol. 2021, 225, 303.e301-303.e317. [CrossRef]

51. Andersson, M.I.; Arancibia-Carcamo, C.V.; Auckland, K.; Baillie, J.K.; Barnes, E.; Beneke, T.; Bibi, S.; Brooks, T.; Carroll, M.; Crook, D.; et al. SARS-CoV-2 RNA detected in blood products from patients with COVID-19 is not associated with infectious virus Wellcome Open Res. 2020, 5, 181. [CrossRef]

52. Despres, H.W.; Mills, M.G.; Shirley, D.J.; Schmidt, M.M.; Huang, M.-L.; Jerome, K.R.; Greninger, A.L.; Bruce, E.A. Quantitative measurement of infectious virus in SARS-CoV-2 Alpha, Delta and Epsilon variants reveals higher infectivity (viral titer:RNA ratio) in clinical samples containing the Delta and Epsilon variants. medRxiv 2021. [CrossRef]

53. Ke, R.; Martinez, P.P.; Smith, R.L.; Gibson, L.L.; Achenbach, C.J.; McFall, S.; Qi, C.; Jacob, J.; Dembele, E.; Bundy, C.; et al Longitudinal analysis of SARS-CoV-2 vaccine breakthrough infections reveal limited infectious virus shedding and restricted tissue distribution. medRxiv 2021. [CrossRef]

54. Puhach, O.; Adea, K.; Hulo, N.; Sattonnet-Roche, P.; Genecand, C.; Iten, A.; Jacquerioz Bausch, F.; Kaiser, L.; Vetter, P.; Eckerle, I.; et al. Infectious viral load in unvaccinated and vaccinated patients infected with SARS-CoV-2 WT, Delta and Omicron. medRxiv 2022. [CrossRef]

55. Singanayagam, A.; Hakki, S.; Dunning, J.; Madon, K.J.; Crone, M.A.; Koycheva, A.; Derqui-Fernandez, N.; Barnett, J.L.; Whitfield, M.G.; Varro, R.; et al. Community transmission and viral load kinetics of the SARS-CoV-2 delta (B.1.617.2) variant in vaccinated and unvaccinated individuals in the UK: A prospective, longitudinal, cohort study. Lancet Infect. Dis. 2021. [CrossRef]

56. Baj, A.; Novazzi, F.; Genoni, A.; Ferrante, F.D.; Taborelli, S.; Pini, B.; Partenope, M.; Valli, M.; Gasperina, D.D.; Capuano, R.; et al. Symptomatic SARS-CoV-2 infections after full schedule BNT162b2 vaccination in seropositive healthcare workers: A case series from a single institution. Emerg. Microbes Infect. 2021, 10, 1254-1256. [CrossRef] [PubMed]

57. Bleier, B.S.; Ramanathan, M., Jr.; Lane, A.P. COVID-19 vaccines may not prevent nasal SARS-CoV-2 infection and asymptomatic transmission. Otolaryngol. Head Neck Surg. Off. J. Am. Acad. Otolaryngol. Head Neck Surg. 2021, 164, 305-307. [CrossRef] [PubMed]

58. Chan, R.W.Y.; Liu, S.; Cheung, J.Y.; Tsun, J.G.S.; Chan, K.C.; Chan, K.Y.Y.; Fung, G.P.G.; Li, A.M.; Lam, H.S. The mucosal and serological immune responses to the novel coronavirus (SARS-CoV-2) vaccines. Front. Immunol. 2021, 12, 744887. [CrossRef] [PubMed]

59. Rosenberg-Friedman, M.; Kigel, A.; Bahar, Y.; Werbner, M.; Alter, J.; Yogev, Y.; Dror, Y.; Lubetzky, R.; Dessau, M.; Gal-Tanamy, M.; et al. BNT162b2 mRNA vaccine elicited antibody response in blood and milk of breastfeeding women. Nat. Commun. 2021, 12, 6222. [CrossRef]

60. Zhao, J.; Zhao, J.; Mangalam, A.K.; Channappanavar, R.; Fett, C.; Meyerholz, D.K.; Agnihothram, S.; Baric, R.S.; David, C.S.; Perlman, S. Airway memory CD4(+) T cells mediate protective immunity against emerging respiratory coronaviruses. Immunity 2016, 44, 1379-1391. [CrossRef] [PubMed]

61. Shim, B.S.; Stadler, K.; Nguyen, H.H.; Yun, C.H.; Kim, D.W.; Chang, J.; Czerkinsky, C.; Song, M.K. Sublingual immunization with recombinant adenovirus encoding SARS-CoV spike protein induces systemic and mucosal immunity without redirection of the virus to the brain. Virol. J. 2012, 9, 215. [CrossRef] [PubMed]

62. Raghuwanshi, D.; Mishra, V.; Das, D.; Kaur, K.; Suresh, M.R. Dendritic cell targeted chitosan nanoparticles for nasal DNA immunization against SARS-CoV nucleocapsid protein. Mol. Pharm. 2012, 9, 946-956. [CrossRef] [PubMed]

63. Gai, W.W.; Zhang, Y.; Zhou, D.H.; Chen, Y.Q.; Yang, J.Y.; Yan, H.M. PIKA provides an adjuvant effect to induce strong mucosal and systemic humoral immunity against SARS-CoV. Virol. Sin. 2011, 26, 81-94. [CrossRef]

64. Lu, B.; Huang, Y.; Huang, L.; Li, B.; Zheng, Z.; Chen, Z.; Chen, J.; Hu, Q.; Wang, H. Effect of mucosal and systemic immunization with virus-like particles of severe acute respiratory syndrome coronavirus in mice. Immunology 2010, 130, 254-261. [CrossRef]

65. Shim, B.S.; Park, S.M.; Quan, J.S.; Jere, D.; Chu, H.; Song, M.K.; Kim, D.W.; Jang, Y.S.; Yang, M.S.; Han, S.H.; et al. Intranasal immunization with plasmid DNA encoding spike protein of SARS-coronavirus/polyethylenimine nanoparticles elicits antigenspecific humoral and cellular immune responses. BMC Immunol. 2010, 11, 65. [CrossRef]

66. Huang, X.; Lu, B.; Yu, W.; Fang, Q.; Liu, L.; Zhuang, K.; Shen, T.; Wang, H.; Tian, P.; Zhang, L.; et al. A novel replication-competent vaccinia vector MVTT is superior to MVA for inducing high levels of neutralizing antibody via mucosal vaccination. PLoS ONE 2009, 4, e4180. [CrossRef]

67. Schulze, K.; Staib, C.; Schätzl, H.M.; Ebensen, T.; Erfle, V.; Guzman, C.A. A prime-boost vaccination protocol optimizes immune responses against the nucleocapsid protein of the SARS coronavirus. Vaccine 2008, 26, 6678-6684. [CrossRef] 
68. Du, L.; Zhao, G.; Lin, Y.; Sui, H.; Chan, C.; Ma, S.; He, Y.; Jiang, S.; Wu, C.; Yuen, K.Y.; et al. Intranasal vaccination of recombinant adeno-associated virus encoding receptor-binding domain of severe acute respiratory syndrome coronavirus (SARS-CoV) spike protein induces strong mucosal immune responses and provides long-term protection against SARS-CoV infection. J. Immunol. 2008, 180, 948-956. [CrossRef]

69. Hu, M.C.; Jones, T.; Kenney, R.T.; Barnard, D.L.; Burt, D.S.; Lowell, G.H. Intranasal Protollin-formulated recombinant SARS S-protein elicits respiratory and serum neutralizing antibodies and protection in mice. Vaccine 2007, 25, 6334-6340. [CrossRef]

70. Luo, F.; Feng, Y.; Liu, M.; Li, P.; Pan, Q.; Jeza, V.T.; Xia, B.; Wu, J.; Zhang, X.L. Type IVB pilus operon promoter controlling expression of the severe acute respiratory syndrome-associated coronavirus nucleocapsid gene in Salmonella enterica Serovar Typhi elicits full immune response by intranasal vaccination. Clin. Vaccine Immunol. CVI 2007, 14, 990-997. [CrossRef] [PubMed]

71. Stephen, J.; Scales, H.E.; Benson, R.A.; Erben, D.; Garside, P.; Brewer, J.M. Neutrophil swarming and extracellular trap formation play a significant role in Alum adjuvant activity. NPJ Vaccines 2017, 2, 1. [CrossRef] [PubMed]

72. Li, E.; Chi, H.; Huang, P.; Yan, F.; Zhang, Y.; Liu, C.; Wang, Z.; Li, G.; Zhang, S.; Mo, R.; et al. A novel bacterium-like particle vaccine displaying the MERS-CoV receptor-binding domain induces specific mucosal and systemic immune responses in mice. Viruses 2019, 11, 799. [CrossRef] [PubMed]

73. Ma, C.; Li, Y.; Wang, L.; Zhao, G.; Tao, X.; Tseng, C.T.; Zhou, Y.; Du, L.; Jiang, S. Intranasal vaccination with recombinant receptor-binding domain of MERS-CoV spike protein induces much stronger local mucosal immune responses than subcutaneous immunization: Implication for designing novel mucosal MERS vaccines. Vaccine 2014, 32, 2100-2108. [CrossRef]

74. Haagmans, B.L.; van den Brand, J.M.; Raj, V.S.; Volz, A.; Wohlsein, P.; Smits, S.L.; Schipper, D.; Bestebroer, T.M.; Okba, N.; Fux, R.; et al. An orthopoxvirus-based vaccine reduces virus excretion after MERS-CoV infection in dromedary camels. Science 2016, 351, 77-81. [CrossRef]

75. Mudgal, R.; Nehul, S.; Tomar, S. Prospects for mucosal vaccine: Shutting the door on SARS-CoV-2. Hum. Vaccines Immunother. 2020, 16, 2921-2931. [CrossRef]

76. Moreno-Fierros, L.; García-Silva, I.; Rosales-Mendoza, S. Development of SARS-CoV-2 vaccines: Should we focus on mucosal immunity? Expert Opin. Biol. Ther. 2020, 20, 831-836. [CrossRef]

77. Park, J.H.; Lee, H.K. Delivery routes for COVID-19 vaccines. Vaccines 2021, 9, 524. [CrossRef] [PubMed]

78. Tiboni, M.; Casettari, L.; Illum, L. Nasal vaccination against SARS-CoV-2: Synergistic or alternative to intramuscular vaccines? Int. J. Pharm. 2021, 603, 120686. [CrossRef]

79. Ashraf, M.U.; Kim, Y.; Kumar, S.; Seo, D.; Ashraf, M.; Bae, Y.S. COVID-19 vaccines (revisited) and oral-mucosal vector system as a potential vaccine platform. Vaccines 2021, 9, 171. [CrossRef] [PubMed]

80. Roozen, G.V.T.; Prins, M.; van Binnendijk, R.; den, G.; Kuiper, V.; Prins, C.; Janse, J.J.; Kruithof, A.C.; Feltkamp, M.C.W.; Kuijer, M.; et al. Tolerability, safety and immunogenicity of intradermal delivery of a fractional dose mRNA-1273 SARS-CoV-2 vaccine in healthy adults as a dose sparing strategy. medRxiv 2021. [CrossRef]

81. Jung, K.Y.; Lim, H.H.; Choi, G.; Choi, J.O. Age-related changes of IgA immunocytes and serum and salivary IgA after tonsillectomy. Acta Oto-Laryngologica. Suppl. 1996, 523, 115-119.

82. Yu, J.; Collins, N.; Mercado, N.B.; McMahan, K.; Chandrashekar, A.; Liu, J.; Anioke, T.; Chang, A.; Giffin, V.; Hope, D.; et al Protective efficacy of gastrointestinal SARS-CoV-2 delivery against intranasal and intratracheal SARS-CoV-2 challenge in rhesus macaques. J. Virol. 2021, JVI0159921. [CrossRef] [PubMed]

83. Du, Y.; Xu, Y.; Feng, J.; Hu, L.; Zhang, Y.; Zhang, B.; Guo, W.; Mai, R.; Chen, L.; Fang, J.; et al. Intranasal administration of a recombinant RBD vaccine induced protective immunity against SARS-CoV-2 in mouse. Vaccine 2021, 39, 2280-2287. [CrossRef] [PubMed]

84. Kim, Y.I.; Kim, D.; Yu, K.M.; Seo, H.D.; Lee, S.A.; Casel, M.A.B.; Jang, S.G.; Kim, S.; Jung, W.; Lai, C.J.; et al. Development of spike receptor-binding domain nanoparticle as a vaccine candidate against SARS-CoV-2 infection in ferrets. Mbio 2021, 12, e00230-21. [CrossRef] [PubMed]

85. Pitcovski, J.; Gruzdev, N.; Abzach, A.; Katz, C.; Ben-Adiva, R.; Brand Schwartz, M.; Yadid, I.; Haviv, H.; Rapoport, I.; Bloch, I.; et al. Oral subunit SARS-CoV-2 vaccine induces systemic neutralizing IgG, IgA and cellular immune responses and can boost neutralizing antibody responses primed by an injected vaccine. bioRxiv 2021. [CrossRef]

86. Sui, Y.; Li, J.; Zhang, R.; Prabhu, S.K.; Elyard, H.A.; Venzon, D.; Cook, A.; Brown, R.E.; Teow, E.; Velasco, J.; et al. Protection against SARS-CoV-2 infection by a mucosal vaccine in rhesus macaques. JCI Insight 2021, 6, e148494. [CrossRef]

87. Sui, Y.; Li, J.; Andersen, H.; Zhang, R.; Prabhu, S.; Hoang, T.; Venzon, D.; Cook, A.; Brown, R.; Teow, E.; et al. An intranasally administrated SARS-CoV-2 beta variant subunit booster vaccine prevents beta variant viral replication in rhesus macaques. bioRxiv 2021. [CrossRef]

88. Jiang, L.; Driedonks, T.; Lowman, M.; Jong, W.S.P.; van den Berg van Saparoea, H.B.; Dhakal, S.; Zhou, R.; Caputo, C.; Littlefield, K.; Sitaras, I.; et al. A bacterial extracellular vesicle-based intranasal vaccine against SARS-CoV-2. bioRxiv 2021. [CrossRef]

89. Rothen, D.A.; Krenger, P.S.; Nonic, A.; Balke, I.; Vogt, A.-C.; Chang, X.; Manenti, A.; Vedovi, F.; Resevica, G.; Walton, S.; et al Intranasal administration of a VLP-based vaccine against COVID-19 induces neutralizing antibodies against SARS-CoV-2 and variants of concerns. bioRxiv 2021. [CrossRef]

90. Bellier, B.; Saura, A.; Lujan, L.; Molina, C.; Lujan, H.D.; Klatzmann, D. A thermostable oral SARS-CoV-2 vaccine induces mucosal and protective immunity. bioRxiv 2021. [CrossRef] 
91. King, R.G.; Silva-Sanchez, A.; Peel, J.N.; Botta, D.; Meza-Perez, S.; Allie, R.; Schultz, M.D.; Liu, M.; Bradley, J.E.; Qiu, S.; et al. Single-dose intranasal administration of AdCOVID elicits systemic and mucosal immunity against SARS-CoV-2 in mice. Vaccines 2020, 9, 881. [CrossRef] [PubMed]

92. Wu, S.; Zhong, G.; Zhang, J.; Shuai, L.; Zhang, Z.; Wen, Z.; Wang, B.; Zhao, Z.; Song, X.; Chen, Y.; et al. A single dose of an adenovirus-vectored vaccine provides protection against SARS-CoV-2 challenge. Nat. Commun. 2020, 11, 4081. [CrossRef]

93. Hassan, A.O.; Kafai, N.M.; Dmitriev, I.P.; Fox, J.M.; Smith, B.K.; Harvey, I.B.; Chen, R.E.; Winkler, E.S.; Wessel, A.W.; Case, J.B.; et al. A single-dose intranasal chad vaccine protects upper and lower respiratory tracts against SARS-CoV-2. Cell 2020, 183, 169-184. [CrossRef]

94. Hassan, A.O.; Shrihari, S.; Gorman, M.J.; Ying, B.; Yuan, D.; Raju, S.; Chen, R.E.; Dmitriev, I.P.; Kashentseva, E.; Adams, L.J.; et al. An intranasal vaccine durably protects against SARS-CoV-2 variants in mice. Cell Rep. 2021, 36, 109452. [CrossRef] [PubMed]

95. Lapuente, D.; Fuchs, J.; Willar, J.; Antao, A.V.; Everlein, V.; Uhlig, N.; Issmail, L.; Schmidt, A.; Oltmanns, F.; Peter, A.S.; et al. Protective mucosal immunity against SARS-CoV-2 after heterologous systemic RNA-mucosal adenoviral vector immunization. Nat. Commun. 2021, 12, 6871. [CrossRef] [PubMed]

96. Chandrasekar, S.S.; Phanse, Y.; Hildebrand, R.E.; Hanafy, M.; Wu, C.W.; Hansen, C.H.; Osorio, J.E.; Suresh, M.; Talaat, A.M. Localized and systemic immune responses against SARS-CoV-2 following mucosal immunization. Vaccines 2021, 9, 132. [CrossRef]

97. Kibler, K.V.; Szczerba, M.; Lake, D.F.; Roeder, A.J.; Rahman, M.; Hogue, B.G.; Wong, L.Y.R.; Perlman, S.; Li, Y.; Jacobs, B.L. Intranasal immunization with a vaccinia virus vaccine vector expressing pre-fusion stabilized SARS-CoV-2 spike fully protected mice against lethal challenge with the heavily mutated mouse-adapted SARS2-N501YMA30 strain of SARS-CoV-2. bioRxiv 2021. [CrossRef]

98. Ku, M.W.; Bourgine, M.; Authié, P.; Lopez, J.; Nemirov, K.; Moncoq, F.; Noirat, A.; Vesin, B.; Nevo, F.; Blanc, C.; et al. Intranasal vaccination with a lentiviral vector protects against SARS-CoV-2 in preclinical animal models. Cell Host Microbe 2021, 29, 236-249. [CrossRef] [PubMed]

99. Peng, K.W.; Carey, T.; Lech, P.; Vandergaast, R.; Munoz-Alia, M.A.; Packiriswamy, N.; Gnanadurai, C.; Krotova, K.; Tesfay, M.; Ziegler, C.; et al. Boosting of SARS-CoV-2 immunity in nonhuman primates using an oral rhabdoviral vaccine. bioRxiv 2021. [CrossRef]

100. Zhou, R.; Wang, P.; Wong, Y.-C.; Xu, H.; Lau, S.-Y.; Liu, L.; Mok, B.W.-Y.; Peng, Q.; Liu, N.; Deng, S.; et al. Nasal prevention of SARS-CoV-2 infection by intranasal influenza-based boost vaccination. bioRxiv 2021. [CrossRef]

101. Sieling, P.; King, T.; Wong, R.; Nguyen, A.; Wnuk, K.; Gabitzsch, E.; Rice, A.; Adisetiyo, H.; Hermreck, M.; Verma, M.; et al. Prime hAd5 spike + nucleocapsid vaccination induces ten-fold increases in mean T-cell responses in phase 1 subjects that are sustained against spike variants. medRxiv 2021. [CrossRef]

102. Moore, A.C.; Dora, E.G.; Peinovich, N.; Tucker, K.P.; Lin, K.; Cortese, M.; Tucker, S.N. Pre-clinical studies of a recombinant adenoviral mucosal vaccine to prevent SARS-CoV-2 infection. bioRxiv 2020. [CrossRef]

103. Wu, S.; Huang, J.; Zhang, Z.; Wu, J.; Zhang, J.; Hu, H.; Zhu, T.; Zhang, J.; Luo, L.; Fan, P.; et al. Safety, tolerability, and immunogenicity of an aerosolised adenovirus type-5 vector-based COVID-19 vaccine (Ad5-nCoV) in adults: Preliminary report of an open-label and randomised phase 1 clinical trial. Lancet Infect. Dis. 2021, 21, 1654-1664. [CrossRef]

104. Read, A.F.; Baigent, S.J.; Powers, C.; Kgosana, L.B.; Blackwell, L.; Smith, L.P.; Kennedy, D.A.; Walkden-Brown, S.W.; Nair, V.K Imperfect vaccination can enhance the transmission of highly virulent pathogens. PLoS Biol. 2015, 13, e1002198. [CrossRef]

105. Bailey, R.I.; Cheng, H.H.; Chase-Topping, M.; Mays, J.K.; Anacleto, O.; Dunn, J.R.; Doeschl-Wilson, A. Pathogen transmission from vaccinated hosts can cause dose-dependent reduction in virulence. PLoS Biol. 2020, 18, e3000619. [CrossRef]

106. Acevedo, M.A.; Dillemuth, F.P.; Flick, A.J.; Faldyn, M.J.; Elderd, B.D. Virulence-driven trade-offs in disease transmission: A meta-analysis. Evol. Int. J. Org. Evol. 2019, 73, 636-647. [CrossRef]

107. Casadevall, A.; Pirofski, L.A. Benefits and costs of animal virulence for microbes. mBio 2019, 10, e00863-19. [CrossRef]

108. Vijgen, L.; Keyaerts, E.; Moës, E.; Thoelen, I.; Wollants, E.; Lemey, P.; Vandamme, A.M.; Van Ranst, M. Complete genomic sequence of human coronavirus OC43: Molecular clock analysis suggests a relatively recent zoonotic coronavirus transmission event. J. Virol. 2005, 79, 1595-1604. [CrossRef]

109. Carter, R.W.; Sanford, J.C. A new look at an old virus: Patterns of mutation accumulation in the human H1N1 influenza virus since 1918. Theor. Biol. Med. Model. 2012, 9, 42. [CrossRef] [PubMed]

110. Christman, M.C.; Kedwaii, A.; Xu, J.; Donis, R.O.; Lu, G. Pandemic (H1N1) 2009 virus revisited: An evolutionary retrospective. Infect. Genet. Evol. J. Mol. Epidemiol. Evol. Genet. Infect. Dis. 2011, 11, 803-811. [CrossRef]

111. Steel, A.; Gubler, D.J.; Bennett, S.N. Natural attenuation of dengue virus type-2 after a series of island outbreaks: A retrospective phylogenetic study of events in the South Pacific three decades ago. Virology 2010, 405, 505-512. [CrossRef] [PubMed]

112. Ariën, K.K.; Vanham, G.; Arts, E.J. Is HIV-1 evolving to a less virulent form in humans? Nat. Rev. Microbiol. 2007, 5, 141-151. [CrossRef] [PubMed]

113. Blanquart, F.; Grabowski, M.K.; Herbeck, J.; Nalugoda, F.; Serwadda, D.; Eller, M.A.; Robb, M.L.; Gray, R.; Kigozi, G.; Laeyendecker, O.; et al. A transmission-virulence evolutionary trade-off explains attenuation of HIV-1 in Uganda. eLife 2016, 5, e20492. [CrossRef] [PubMed]

114. Dominant Delta Variant 'May Mutate Itself into Extinction', Scientists Say. Available online: https://nypost.com/2021/11/22 /dominant-delta-variant-may-mutate-itself-into-extinction-scientists-say/ (accessed on 20 December 2021). 
115. Summary of Designated AY Lineages. Available online: https://www.pango.network/summary-of-designated-ay-lineages/ (accessed on 25 November 2021).

116. Bernasconi, A.; Pinoli, P.; Al Khalaf, R.; Alfonsi, T.; Canakoglu, A.; Cilibrasi, L.; Ceri, S. Report on Omicron Spike Mutations on Epitopes and Immunological/Epidemiological/Kinetics effects from Literature. Available online: https://virological.org/t/reporton-omicron-spike-mutations-on-epitopes-and-immunological-epidemiological-kinetics-effects-from-literature/770 (accessed on 20 December 2021).

117. Venkatakrishnan, A.; Praveen, A.; Lenehan, P.; Suratekar, R.; Raghunathan, B.; Niesen, M.; Soundararajan, V. Omicron Variant of SARS-CoV-2 Harbors a Unique Insertion Mutation of Putative Viral or Human Genomic Origin. Available online: https: / / osf.io/f7txy/ (accessed on 20 December 2021).

118. Armengaud, J.; Delaunay-Moisan, A.; Thuret, J.-Y.; van Anken, E.; Acosta-Alvear, D.; Aragón, T.; Arias, C.; Blondel, M.; Braakman, I.; Collet, J.-F.; et al. The importance of naturally attenuated SARS-CoV-2in the fight against COVID-19. Environ. Microbiol. 2020, 22, 1997-2000. [CrossRef] [PubMed]

119. De Klerk, A.; Swanepoel, P.I.; Lourens, R.F.; Zondo, M.; Abodunran, I.; Lytras, S.; MacLean, O.; Robertson, D.L.; Kosakovsky Pond, S.L.; Zehr, J.D.; et al. Conserved recombination patterns across coronavirus subgenera. bioRxiv 2021. [CrossRef]

120. Brewer, W.H.; Smith, F.D.; Sanford, J.C. Information loss: Potential for accelerating natural genetic attenuation of RNA viruses. In Biological Information; World Scientific: Singapore, 2013; pp. 369-384. [CrossRef]

121. Chinese SARS Molecular Epidemiology Consortium. Molecular evolution of the SARS coronavirus during the course of the SARS epidemic in China. Science 2004, 303, 1666-1669. [CrossRef] [PubMed]

122. Bergman, P.; Blennow, O.; Hansson, L.; Mielke, S.; Nowak, P.; Chen, P.; Söderdahl, G.; Österborg, A.; Edvard Smith, C.I.; Wullimann, D.; et al. Safety and efficacy of the mRNA BNT162b2 vaccine against SARS-CoV-2 in five groups of immunocompromised patients and healthy controls in a prospective open-label clinical trial. EBioMedicine 2021, 74, 103705. [CrossRef]

123. Niesen, M.; Anand, P.; Silvert, E.; Suratekar, R.; Pawlowski, C.; Ghosh, P.; Lenehan, P.; Hughes, T.; Zemmour, D.; OHoro, J.C.; et al. COVID-19 vaccines dampen genomic diversity of SARS-CoV-2: Unvaccinated patients exhibit more antigenic mutational variance. medRxiv 2021. [CrossRef]

124. Focosi, D.; Maggi, F.; Franchini, M.; McConnell, S.; Casadevall, A. Analysis of immune escape variants from antibody-based therapeutics against COVID-19: A systematic review. Int. J. Mol. Sci. 2021, 23, 29. [CrossRef] 